\title{
Comparative Characteristics of Metabolic Parameters in Patients with Psoriasis and Lichen Planus
}

\author{
Alla Bilovol ${ }^{1}$, Svitlana Tkachenko ${ }^{1}$, Oleksandra Havryliuk ${ }^{1,2 *}$ (D) , Alla Berehehova ${ }^{1}$ (D), Nataliia Pustova ${ }^{1}$, Nataliia Kolhanova ${ }^{1}$, \\ Yulia Drozd ${ }^{1}$ (D) \\ ${ }^{1}$ Department of Dermatology, Kharkiv National Medical University, Venereology and Medical Cosmetology, Kharkiv, Ukraine; \\ ${ }^{2}$ SE "Institute of Dermatology and Venereology of National Academy of Medical Sciences of Ukraine", Kharkiv, Ukraine
}

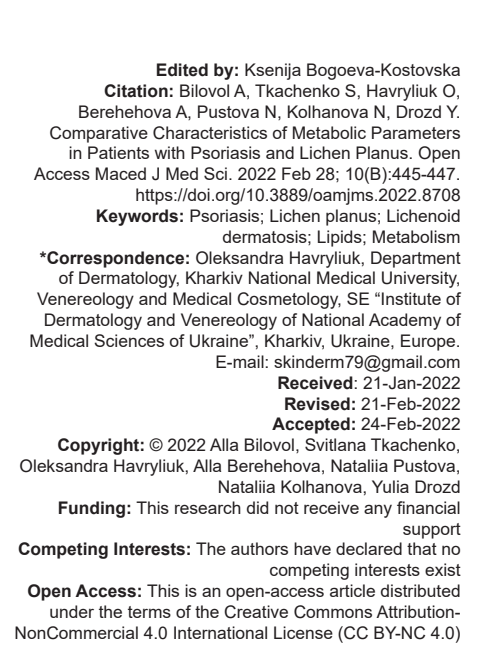

\section{Abstract}

AIM: The aim of the study was to assess metabolic parameters in patients with lichenoid dermatoses.

METHODS: The study of indicators of metabolic processes was performed on two groups of patients: first group consisted of 50 patients with psoriasis, of whom there were 20 women and 30 men, the average age was 41.3 years: second group included 50 patients with lichen planus, including 23 women and 27 men, the average age was 40.9 years. The control group consisted of 15 healthy individuals, comparable age and gender, whose indicators were considered normal.

CONCLUSIONS: Deviations of lipid metabolism in patients with psoriasis and lichen planus were detected, which were unidirectional with a significant increase in total cholesterol (27\% and $30 \%$, respectively) and low-density lipoprotein cholesterol ( $17 \%$ and $21 \%$, respectively).

\section{Introduction}

Numerous studies in recent years have revealed the polysystemic nature of chronic lichenoid dermatoses, which are associated with a variety of infectious, autoimmune, metabolic, and inflammatory diseases of various internal organs and systems [1], [2]. There is a close link between psoriasis and metabolic syndrome, but for lichen planus (LP) such comorbidity is less specific [3], [4], [5]. Metabolic disorders in lichenoid dermatoses are more related to carbohydrate-lipid metabolism, but the methods of metabolic correction recorded in modern protocols are not personalized, or even specific to each of the lichenoid dermatoses [4], [6], [7], [8], [9], [10]. Recent studies have shown an association between systemic inflammation and dyslipidemia in patients with psoriasis of varying severity in loco [6], [11], as well as between fatty acid metabolism and cytokine production in psoriatic plaques. Disorders of lipid metabolism were studied in terms of the relationship with HLA antigens, which confirmed the genetic nature of the comorbidity of psoriasis [12]. Obesity is a known risk factor for psoriasis [13], [14]. This relationship is two-way: on the one hand, visceral obesity produces inflammatory cytokines, which contribute to the development of psoriasis, on the other-psoriasis causes metabolic disorders that provoke obesity [15]. In particular, the risk of developing psoriasis in patients with obesity is twice as high as in subjects with normal body weight [16]. There is evidence that increasing the body mass index by one unit increases the risk of psoriasis by $9 \%$, and in patients with psoriasis increases PASI by $7 \%$ [14].

A number of works have also been devoted to the study of metabolic disorders in LP. A metaanalysis of 7 observational studies revealed an association of LP with dyslipidemia, which occurred 1.74 times more often than in controls. In this study, hypertriglyceridemia, increased levels of low-density lipoprotein and blood cholesterol and decreased levels of high-density lipoprotein were recorded in patients with LP [4]. Concomitant hyperlipidemia also adversely affects the prognosis of LP. Thus, in the study of Yew 
(2016), patients with LP associated with hyperlipidemia and/or diabetes showed a significantly lower degree of improvement after dermatological treatment compared with patients who did not have such concomitant pathology [14]. There is a suggestion that a violation of the ratio of fatty acids in patients with oral LP may affect the development of dermatosis. Progression of the disease was associated with eicosapentaenoic acid deficiency with a relative increase in the content of lauric and linoleic acids in the blood of patients with oral LP [15].

The study is a fragment of the research work of the Department of Dermatology, Venereology and Medical Cosmetology of Kharkiv National Medical University "Clinical and pathogenetic aspects of chronic lichenoid dermatoses and methods of their correction" № 0119 U002910 (2019-2021).

The aim of the study was to assess metabolic parameters in patients with lichenoid dermatoses.

\section{Methods}

Determination of serum fasting glucose was performed by glucose oxidase method, the results were given in $\mathrm{mmol} / \mathrm{l}$. The range of recommended normal values was provided for each specific set but was not higher than $5.9 \mathrm{mmol} / \mathrm{l}$. Indicators of lipid metabolism included the assessment of total cholesterol ( $\mathrm{TCH})$, high-density lipoprotein cholesterol (HDL-C), and low-density lipoprotein cholesterol (LDL-C). The concentration of $\mathrm{TCH}$ in the serum was determined using an industrial test system from "SpainLab" (Ukraine) on a biochemical analyzer "Labline-80" (Austria). The concentration of HDL-C and LDL-C in the serum was determined using a commercial test system from DAC-SpectroMed (Moldova) on a biochemical analyzer "Labline-80" (Austria) 12-14. Modern software was used for statistical processing of the obtained data: Statistica for Windows software package, Excel spreadsheet editor (Microsoft). Statistical processing of the obtained data was performed using the program "Microsoft Excel 2010" with a minimum reliability of 95\% at $p<0.05$. Methods of descriptive statistics were used to calculate the arithmetic mean $(\mathrm{M})$, the arithmetic mean error $(m)$, the standard deviation $\left(\sigma^{\prime}\right)$. To assess the reliability of the difference between the groups used an odd t-test Student with a preliminary check of the normality of the distribution option [15]. The study of indicators of metabolic processes was performed on two patients groups with a confirmed diagnosis of psoriasis and LP, who were examined and treated in the inpatient and outpatient dermatologic units. The first group consisted of 50 patients with psoriasis, of whom there were 20 women and 30 men, the average age was 41.3 years. The second group included 50 patients with LP, including 23 women and 27 men, the average age was 40.9 years. The control group consisted of 15 healthy persons, compared with age and gender, whose indicators were considered normal.

\section{Results and Discussion}

The analysis of indicators of metabolic processes revealed deviations of lipid metabolism against the background of the tendency to hyperglycemia in patients with lichenoid dermatoses (Table 1).

Table 1: Indicators of metabolic processes in patients with psoriasis and lichen planus

\begin{tabular}{llll}
\hline Indicators & Psoriasis $(n=50)$ & LP $(n=50)$ & Control $(n=15)$ \\
\hline Glucose $(\mathrm{mmol} / \mathrm{l})$ & $5.03 \pm 0.13$ & $5.34 \pm 0.82$ & $4.65 \pm 0.54$ \\
TCH $(\mathrm{mmol} / \mathrm{l})$ & $5.89 \pm 0.97^{*}$ & $6.02 \pm 0.17^{*}$ & $4.64 \pm 0.24$ \\
LDL-C $(\mathrm{mmol} / \mathrm{l})$ & $4.53 \pm 0.18^{*}$ & $4.63 \pm 0.18^{*}$ & $3.84 \pm 0.16$ \\
HDL-C $(\mathrm{mmol} / \mathrm{l})$ & $1,12 \pm 0,05$ & $1,16 \pm 0,05$ & $1,16 \pm 0,07$ \\
\hline${ }^{*}$ significantly different from the control $(p<0.05) ;{ }^{*}$ significantly different from the psoriasis $(\mathrm{p}<0.05)$, \\
LP: Lichen planus, LDL-C: Low-density lipoprotein cholesterol, HDL-C: High-density lipoprotein cholesterol.
\end{tabular}

There was a probable increase in the serum level of total cholesterol in patients with psoriasis (by $27 \%$ ) and, to a greater extent, patients with LP (by $30 \%$ ), relative to the group of healthy donors. There was also a probable increase in LDL-C relative to control in the group of patients with psoriasis (by 17\%) and in the group of patients with LP (by $21 \%$ ). There was no significant difference in the level of LDL-C between the groups of patients with lichenoid dermatoses, but the rate was higher in the group of LP $(2 \%)$. The level of HDL-C was lower relative to control in patients with psoriasis (by $3.5 \%$ ), but this difference was not significant. The level of HDL-C in patients with LP did not differ from the control and was higher than the corresponding figure in patients with psoriasis. Glucose levels in patients with lichenoid dermatoses were higher than control values ( $8 \%$ in patients with psoriasis and $14 \%$ in patients with LP respectively), but the difference was not significant. In patients with LP, serum glucose was slightly higher $(6 \%)$ than in patients with psoriasis, but both indicators were within the reference range.

The association of psoriasis with lipid disorders is a well-known fact in medical science. Over the past century, a number of authors have considered psoriasis as "skin lipoidosis" or "cholesterol diathesis," also recording the accumulation of cholesterol in psoriatic plaques, the association of lipid accumulation in injured skin with the development of kebnerization [11]. We have found the deviations of lipid metabolism in patients with lichenoid dermatoses, which were unidirectional in both patients with psoriasis and in patients with LP, and were characterized by a significant increase in $\mathrm{TCH}$ and LDL-C. In our opinion, the identified changes require mandatory screening of the above indicators in patients with lichenoid dermatoses and pathogenetic metabolic correction in the overall management strategy of lihenoid dermatoses, and in each individual case. 


\section{Conclusions}

Deviations of lipid metabolism in patients with psoriasis and LP were detected, which were unidirectional with a significant increase in total cholesterol $(27 \%$ and $30 \%$, respectively) and LDL-C ( $17 \%$ and $21 \%$, respectively).

\section{References}

1. Slesarenko NA, Utz SR, Bakulev AL, Davtyan VA, Yepifanova AY, Reshetnikova YM, et al. Sluchay sochetaniya shipovidnogo folliculyarnogo keratoza Krokkera-Adamsona, krasnogo ploskogo lishaya i syndroma Littla-Lassuera u yunoshi 17 let. [A case of a combination of Crocker-Adamson follicular spinulosa, lichen acuminatus and Little-Lassueur syndrome]. Vestnik Dermatol Venerol. 2014;4:68-74.

2. Yeung H, Takeshita J, Mehta NN, Kimmel SE, Ogdie A Margolis DJ, et al. Psoriasis sevirity and the prevalence of major medical comorbidity: A population-based study. JAMA Dermatol. 2013;140(10):1173-9. http://doi.org/10.1001/ jamadermatol.2013.5015 PMid:23925466

3. Polic MV, Miskulin M, Smolic M, Kralik K, Miskulin I, Berkovic MC, et al. Psoriasis severity-a risk factor of insulin resistance independent of metabolic syndrome. Int $\mathrm{J}$ Environ Res Public Health. 2018;15(7):1486. http://doi.org/10.3390/ijerph15071486 PMid:30011841

4. Lai YC, Yew YW, Schwartz RA. Lichen planus and dyslipidemia: A systematic review and meta-analysis of observational studies. Int J Dermatol. 2016;55(5):e295-304. http://doi.org/10.1111/ ijd.13234

\section{PMid:26873870}

5. Arias-Santiago S, Buendia-Eisman A, Aneiros-Fernandez J, Girón-Prieto MS, Gutiérrez-Salmerón MT, Mellado VG, et al. Cardiovascular risk factors in patients with lichen planus. Am J Med. 2011;124(6):543-8. http://doi.org/10.1016/j. amjmed.2010.12.025

PMid:21605731

6. Alkammaz AM, Stepanenko RL. Pokaznyki lipidnogo obminu u hvoryh na psoriaz z osinnyo-litnym i pozasezonnym (zmishanym) typami perebuhu ta yihnye znachennya dlya patogenezu dermatozu [Indicators of lipid metabolism in patients with psoriasis with autumn-winter, spring-summer and off-season (mixed) types of current and their importance for the pathogenesis of dermatosis.] Ukranian J Dermatol Venereol Cosmetol. 2018;2(69):25-37.

7. Alkammaz AM, Stepanenko RL. Lipidnyy obmin u shkiri hvorykh na psoriaz ta perspectyvy vyvchennya znachennya yoho porushen' u patohenezi dermatozu. [Lipid metabolism in the skin of patients with psoriasis and prospects for studying the importance of its disorders in the pathogenesis of dermatosis]. Ukranian J Dermatol Venereol Cosmetol. 2019;2(73):93-8.

8. Orlov EV, Arnautova MS, Gergel' NI. Otsenka metabolicheskogo statusa i kletochnogo sostava krovi pri psoriaze i psoriaticheskom artrite [Assessment of metabolic status and cellular composition of blood in psoriasis and psoriatic arthritis]. Med Almanac. 2013;5(28):197-200.

9. Falko YV, Khyshyktuyev BC, Karavayeva TM, et al. Patogeneticheskiye aspekty obmena zhirnykh kislot s korotkoy tsep'yu i produktsii tsitokinov v porazhennykh uchastkakh kozhi pri psoriaze [Pathogenetic aspects of fat acid metabolism with short chain and production of cytokis in target affected areas of skin under psoriasis]. Clin Lab Diagn. 2012;1:33-6.

10. Nekipelova AV, Kalatushkina GB. HLA-antigeny u bol'nykh psoriazom i ikh vzaimosvyaz' s pokazatelyami lipidnogo obmena [HLA antigens and their correlation with lipid metabolism indices in patients with psoriasis]. Yakut Med J. 2014;1(45):7-9.

11. Barrea L, Nappi F, di Somma C, Savanelli MC, Falco A, Balato A, et al. Environmental risk factors in psoriasis: The point of view of the nutritionist. Int J Environ Res Public Health. 2016;13(5):743. http://doi.org/10.3390/ijerph13070743 PMid:27455297

12. Jensen $P$, Skov L. Psoriasis and obesity. Dermatology 2016;232(6):633-9. http://doi.org/10.1159/000455840 PMid:28226326

13. Carrascosa JM, Rocamora V, Fernandez-Torres RM, JimenezPuya R, Moreno JC, Coll-Puigserver N, et al. Obesity and psoriasis: Inflammatory nature of obesity, relationship between psoriasis and obesity, and therapeutic implications. Actas Dermosifiliogr. 2014;105(1):31-44. http://doi.org/10.1016/j. ad.2012.08.003

PMid:23177976

14. Debbaneh M, Millsop JW, Bhatia BK, Koo J, Liao W. Diet and psoriasis, Part I: Impact of weight loss interventions. J Am Acad Dermatol. 2014;71(1):133-40. http://doi.org/10.1016/j. jaad.2014.02.012 PMid:24709272

15. Yew YW, Lai YC, Chan R. Lichen planus epidemiology study. Ann Acad Med. 2016;45(11):516-9. 